日消外会誌 $22(1): 115 \sim 118,1989$ 年

症例報告

食道癌術後挙上胃管に発生した胃癌症例と本邦報告例の検討

\begin{tabular}{|c|c|c|c|c|c|c|c|}
\hline & & 東京女 & 子医科大 & 属第二 & 院外科 & & \\
\hline 小川 & 智子 & 小川 & 健治 & 矢川 & 裕一 & 稲葉 & 俊三 \\
\hline 勝部 & 隆男 & 遠田 & 譲 & 大谷 & 洋一 & 菊池 & 友允 \\
\hline 芳賀 & 駿介 & 梶原 & 哲郎 & & & & \\
\hline
\end{tabular}

\title{
A CASE OF CARCINOMA OF THE GASTRIC ROLL AFTER RADICAL RESECTION FOR ESOPHAGEAL CANCER
}

\author{
Tomoko OGAWA, Kenji OGAWA, Hirokazu YAGAWA, \\ Shunzo INABA, Takao KATSUBE, Jyo TOHDA, \\ Youichi OHTANI, Tomomitsu KIKUCHI, Shunsuke HAGA \\ and Tetsuro KAJIWARA
}

Department of Surgery, Tokyo Women's Medical College Daini Hospital

索引用語：挙上胃管癌, 食道癌

はじめに

近年, 手術手技の進歩や集学的治療の発達によって, 食道癌の治療成績は向上している"， それに伴って長 期生存例も堌加し, 食道癌術後他の藏器に第 2 癌が発 生する症例も報告されるよらになった2).しかし，その 中で食道癌術後, 再建に用いた挙上胃管に発生した胃 癌との異時性重複癌の報告は少なく, 現在までに集計 しえた症例は33例にすぎない.本稿では，われわれの 経験した挙上胃管癌の 1 例を報告するとともに，本邦 に拈ける症例を集計し，その結果を検討した。

$$
\text { 症例 }
$$

症例：59歳, 男性。

主訴: 嚥下障害, 腫瘤触知, 貧血.

家族歴：特記すべさことなし。

既往歴：昭和 58 年, 55歳時, 胸部食道癌, Ei Im ラ セン型の診断で, 術前コバルトを $30 \mathrm{~Gy}$ 照射後, 8 月 22 日右開胸開腹胸部食道全摘術施行, 再建は胸壁前食道 胃吻合術が行われた。切除標本をみると, 癌腫は 4.2 $\mathrm{cm} \times 2.4 \mathrm{~cm}$ の潰瘍浸潤型の食道癌で（図 1), 病理組 織診断では，分化型扁平上皮癌であった(図 2 )。食道 癌取扱い規約 ${ }^{3)}$ による組織学的 stage 分類によると， $\mathrm{a}_{2}, \mathrm{n}\left(\right.$ ( ), $\mathrm{M}_{0}, \mathrm{Pl}_{0}$, stage III であった。術後照射

<1988年10月12日受理>別刷請求先：小川 智子 =116 東京都荒川区西尾久 2-1-10 東京女子医 科大学第二病院外科
図 1 食道切除標本. 中, 下部食道に $4.2 \times 2.4 \mathrm{~cm}$ の漬 湯浸潤型の食道癌を認める。

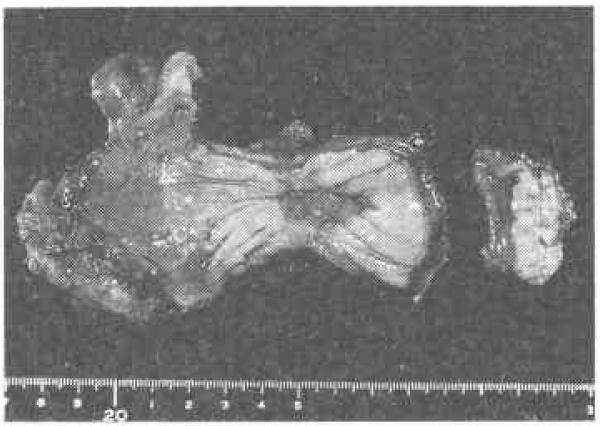

図 2 食道切除標本病理組織像. 角化真珠を形成する 分化型扁平上皮癌で, 腫瘍細胞は中等度の核異型を 有する。（H.E. $\times 100 ）$

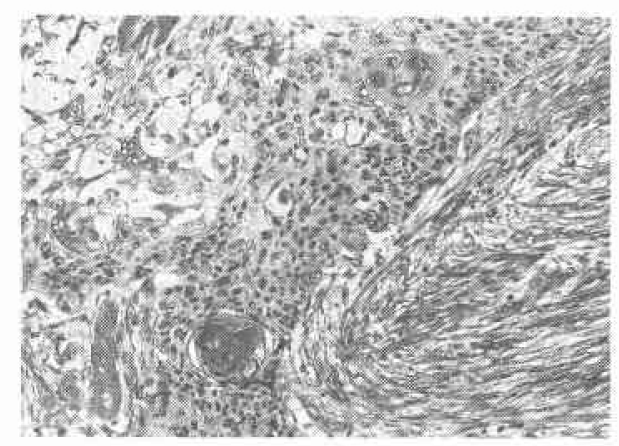


コバルト $50 \mathrm{~Gy}$ 施行後，経過良好にて退院，近医に通院

していた。

現病歴：食道癌切除後 3 年 10 か月目の昭和 62 年 6 月，59歳時，揹下困難出現，さらに心窩部に腫瘤を触 知したことから近医受䛦，高度の賽血を指摘され，再 び当科紹介入院となった。

入院時現症：身長 $163 \mathrm{~cm}$, 体重 $45 \mathrm{~kg}$, 栄養中等度, 血压 $140 / 90 \mathrm{mmHg}$ ，脈拍 90 ，眼䀫結膜に高度の貧血を 認めた。また心窩部に腫瘤を触知した。畽瘤は，鶏眆 大，弾性硬，表面凹凸不整で皮膚との可動性は不良で あった，肝脾腫は触知せず，また表在りンパ節も触れ なかった。

入院時検查成績：末梢血へモグロビン值 $5.5 \mathrm{~g} / \mathrm{dl}$, 赤 血球数 $240 \times 10^{4} / \mathrm{mm}^{3}$ と高度の貧血が認められたが, 総 蛋白 $6.5 \mathrm{~g} / \mathrm{dl}$, アルブミン $3.9 \mathrm{~g} / \mathrm{dl}, \mathrm{GOT} 56 \mathrm{IU} / l, \mathrm{GPT}$ $26 \mathrm{IU} / l, B \mathrm{BUN} 19.6 \mathrm{mg} / \mathrm{dl}$, クレアチニン $0.77 \mathrm{mg} / \mathrm{dl}$, 総ビリルビン $1.0 \mathrm{mg} / \mathrm{dl}$, 血清アミラーゼ $143 \mathrm{IU} / l$ と他 の血液検查, 生化学検査に異常はなかった。腫瘍マー カーでは, Immuno suppresive Acidic Protein が 1，153と上昇していたが, Carcino-embrynic Antigen, $\alpha$-feto protein など他はすべて正常範囲内であった。 便潜血では, オルトトリジン法( $\mathrm{H}$ ), グアヤック法(卅) といずれも陽性を示した。

入院時検查所見：上部消化管造影では，挙上胃管下 部に全周性の著明な狭窄像を呈し，その口側胃管は高 度拡張をきたしていた。さらに狭窄部には硬化像を認 め，一部にバリウムの貯留があり，深い宿凹を有する 腫瘤形成像を呈していた(図 3 )。内視鏡検査では，同 部に全周性の著明な狭窄があり，ファイバースコープ は通過せず，狭窄部よりの生検は施行できなかった。 しかしその口側の粘膜面には異常はなかった。超音波 検査, computed tomography 検査では，胃壁の肥厚を 認めたが，リンパ節の腫大，肝転移などは認められな かった。

以上より，挙上胃管に発生した切除可能な胃癌と診 断した。また食道癌の再発は認めなかった。

手術所見：昭和62年 6 月 24 日, 前胸部の正中に皮切 を加光，皮下組䅧を䟝離後挙上胃管を露出し，腹部は 正中切開にて開腹した。腫瘤は胃管下部にあり，手拳 大で可動性不良であった。癌組織は漿膜面に明らかに 露出しており，一部皮下周囲組織に浸潤が疑がわれた。 しかし肝転移，腹膜播種性転移は認めなかった。これ らより治癒切除可能と判断，浸潤と思われる皮下周囲 組織とともに举上胃管切除を施行した。なお，リンパ
因 3 胃管造影。挙上胃管下部に著明な狭窄像を認め た.

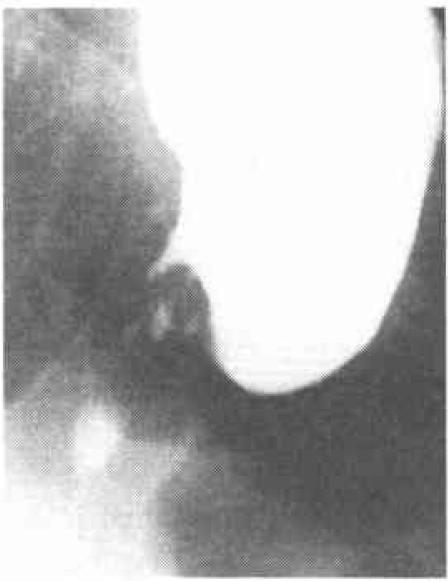

困 4 挙上胃管切除標本. 胃管下部に $5.0 \times 5.5 \mathrm{~cm}$ の IIC 類似進行癌を認める.

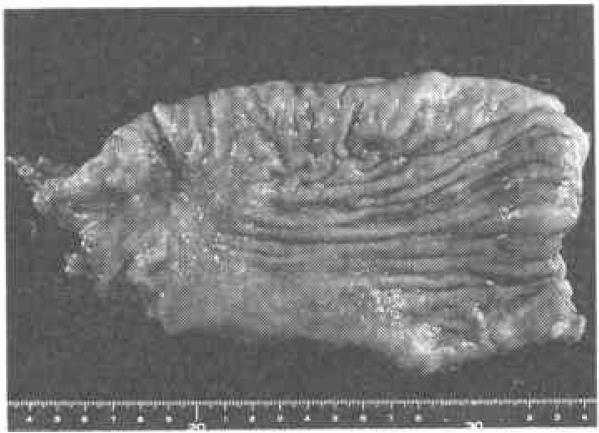

図 5 挙上胃管切除標本病理組織像. 細胞内に小褧胞 や粘液空胞を有する腫湯細胞の充実性又法索状增殖 を認める。（H.E. ×100）

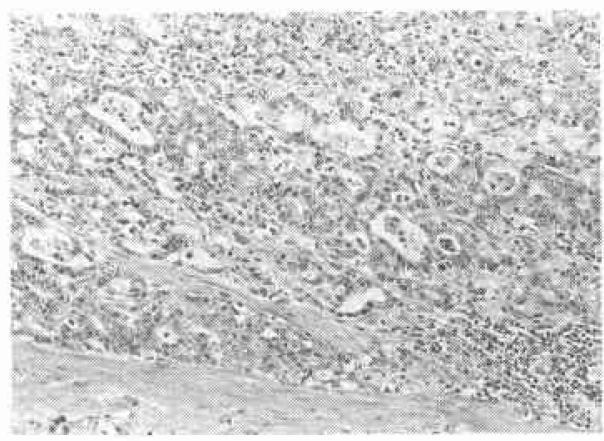

節は近傍のものを郭清した。再建は胸壁前頸部食道空 腸間右半結腸有茎移植術を施行した。 
表 1 食道癌術後挙上胃管に発生した胃癌症例

\begin{tabular}{|c|c|c|c|c|c|c|c|c|}
\hline No. & 政 告 者 & 年 次 & 年橉 & 俵 & 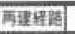 & 胃痓まての期间 & 罩㷥治癔方法 & 予 嵝 \\
\hline 1 & 森(東北大) & 1972 & 44 & $\hat{\delta}$ & 问堙内 & 9年 & 非切除 & 1 年以内 \\
\hline 2 & 秋山(虎の門) & 1973 & 57 & $\hat{3}$ & 胸壁前 & 1 年 4 カ月 & 部分切除+照射 & 7年9力月 \\
\hline 3 & 飯挥(国立カンセンター) & 1975 & 62 & $\hat{b}$ & (1) & 1 年6力月 & 切除結晹再建 & 3力月 \\
\hline 4 & נ & " & 64 & 早 & 因典嵝 & 4年6力月 & 非切除 & 3カ月 \\
\hline 5 & 高楊(悪研) & $n$ & 50 & 8 & 细壁而 & 10年 & 切除結腸再建 & 10カ月 \\
\hline 6 & \# & $" \prime$ & 52 & 8 & "1 & 4年 & 部分切除空膘再建 & 11カ月 \\
\hline 7 & 井手(女子医大消化器センター) & $n$ & 56 & 9 & נ & 18年 & 非切除十照射 & 11カ月 \\
\hline 8 & $\pi$ & "n & 64 & 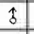 & \# & 6年 & 切除結腸再建 & 23日 \\
\hline 9 & $\mu$ & 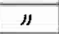 & 62 & 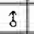 & $\mu$ & 3年6カ月 & 部分切除 & 4年6力月 \\
\hline 10 & $\prime \prime$ & $"$ & 62 & 8 & \# & 10年 & 部分切除 & 3年6力月 \\
\hline 11 & 北村(岡山済生会) & 1976 & 64 & 7 & 胸貫溇 & 6年 & 非切除 & 不明 \\
\hline 12 & 甲(大阪存立成人センター) & 1978 & 64 & $\delta$ & 胸㚙内 & 2年 & 非场绦 & 45日 \\
\hline 13 & 久米川(女子医大消化器センター) & "1 & 58 & $\delta$ & 壁前 & 3年 & 切除結腸再建 & 1 年 \\
\hline 14 & נ) & "n & 56 & $\hat{\delta}$ & $\pi$ & 3年 & 切除結腸再建 & 6力月 \\
\hline 15 & $n$ & 1979 & 65 & $\delta$ & $\mu$ & 6年 & 切除結腸再建 & 5 力月 \\
\hline 16 & 勆重(東邦医大) & "1 & 55 & I & 绹骨後 & 47 & 非切除 & 1 カ月 \\
\hline 17 & 要内(東海大) & 11 & 65 & $\hat{b}$ & 胸傰内 & 2年 2 力月 & 非切除 & 2力月 \\
\hline 18 & $n$ & "1 & 54 & $t$ & 胸骨媵 & 11年 & 切除結腸再建 & 7 л月生 \\
\hline 19 & 奧岛(女子医大消化器センター) & 1980 & 56 & 3 & 胸壁前 & 3年 & 切除結腸再建 & 45日 \\
\hline 20 & $n$ & $n$ & 71 & 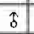 & "I & 5年 & 切除結腸再建 & 5 力月 \\
\hline 21 & ") & 11 & 60 & 8 & m & 8年 & 切除結腸再建 & 1年生 \\
\hline 22 & 池内(国立東京第二) & 1982 & & 3 & 不 $\quad$ 明 & 9年 & 非切除 & 5 カ月 \\
\hline 23 & 金井(東大第 2 外料) & $" 1$ & 57 & $\hat{b}$ & 胸壁前 & 1 年 4 力月 & 部分切除 & 7年 \\
\hline 24 & 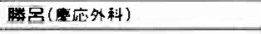 & $" 1$ & 68 & 3 & $\pi$ & 6年 & 部分切除 & 不明 \\
\hline 25 & 䓥島(札愰医科) & $\prime \prime$ & 69 & 8 & $" 1$ & 1 年5力月 & 郚分勀除 & 6カ月 \\
\hline 26 & "1 & 11 & 84 & 3 & $n$ & 14年 & 非切除 & 不明 \\
\hline 27 & 松原(盒研) & II & 56 & 8 & 胸䶼太 & 4年 & 切除 & 9カ月 \\
\hline 28 & " & נ1 & 59 & 8 & 胸壁前 & 10年5力月 & 切除結腸再建 & 10カ月 \\
\hline 29 & נI & "1 & 77 & 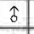 & 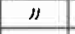 & 5年 & 切除空腸再建 & 1年 4力月 \\
\hline 30 & J1 & "1 & 77 & b) & $\mu$ & 10年7 カ月 & 切除結愣再建 & 10カ月 \\
\hline 31 & 佐故(日大第 1 外科) & 1983 & 70 & : & 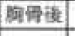 & 8 年 & 切除罙澪再建 & 8 力月生 \\
\hline 32 & 紙田(敃田総合病院) & 1984 & 66 & 8 & $"$ & 6年6力月 & 切除結腸再建 & 14力月 \\
\hline 33 & 本田(東大医科祥研究所) & 11 & 55 & $\hat{\varepsilon}$ & 胸壁前 & 2年6力月 & 切除空腸再建 & 不明 \\
\hline 34 & 自騷例 & 1988 & 59 & $\hat{\delta}$ & 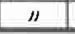 & 3年10力月 & 切除結腸再建 & 5力月 \\
\hline
\end{tabular}

摘出標本所見：癌腫は $5.0 \times 5.5 \mathrm{~cm}$ の IIc 類似進行 癌で(図 4 ), 病理組織診断では低分化型腺癌であった (図 5 ). 贯癌取扱い規的 ${ }^{4}$ による組織学的 stage 分類 によると， $\mathrm{H}_{0} ， \mathrm{P}_{0}, \mathrm{n}_{1}(+)$, se, stage III であった。 術後経過は良好で，昭和62年 8 月 6 日退院した。退院 後, 経過は順調であったが, 同年11月初旬, 腎不全併 発し，11月20日死亡した。

\section{考察}

多発性原発性悪性腫湯の定義は, 1879年 Billroth ${ }^{5)}$ はじめて発表してから，いろいろの変遷を経て, 現在 は1932年 Warren \& Gates ${ }^{6}$ の提言した「括の招のの腫 場は離れて存在し，拉いの間に従属性がないもの」 といら定義が広く使用されている。そこで，まずこの 定義にしたがって食道と胃との重複癌症例の頻度につ いてみた。1956年 Goodner ${ }^{7)}$ は1,315例の食道癌症例 中, 胃癌との重複は 4 例 $(0.3 \%)$ と報告している，ま た本邦では1963年中山ら ${ }^{8)}$ が1,506例の食道癌症例中, 胃癌との重複は 7 例 $(0.5 \%)$ との報告がある、さらに， 阿保ら ${ }^{2}$ は全国 63 施設中, 胃癌之の重複は2 48 例
（2.1\%）あり，重複藏器の中では胃がもっとも多かっ たとしている。その内訳をみると, 同時性186例 (1.6\%)，異時性62例（0.5\%）である。このように食 道と胃との重複癌は少ないが，とくに異時性重複癌は まれである。なかでも自験例のよらな食道癌術後挙上 胃管に胃癌の発生をみた症例はきわめてまれである。

そこで, 食道癌術後挙上胃管に発生した胃癌の本邦 報告例を集計してみると，現在まで自験例を含めて 34 例にすぎない(9) 17).これら34例を検討した。 2 次癌と しての胃癌診療時年龄は44歳から84歳まであり, 平均 61.8 歳となり，50～60歳代に27例（81.8\%）と多くみ られた，性別では男性31例，女性 3 例であり，男性が 圧倒的に多かった，自験例も59歳，男性であり，この 集計結果の範囲内にあった。

初回手術より胃癌発㒻までの期間は，1年 4 か月か ら10年 7 かに抽よ゙，平均6.0年であった，自験例の 胃癌発見までの期間は， 3 年10か月とやや短かった。

主訴をみると, 腫瘤触知, 燕下障害, 貧血, 定期検 查, 剖検などであるが, 腫瘤触知が $60 \%$ 
自験例む腫瘤触知で来院しており, 胸壁前再建の施行 されている症例では，患者みずから腫瘤に気付き来院 する場合が多いと思われる。

次に挙上胃管癌に対する切除率を検討した。非切除 に敃わった症例は 9 例(26.5\%)，部分切除が施行され た症例は 7 例(20.6\%), 切除可能であった症例は18例 (52.9\%)であった。このように挙上胃管癌の切除はか なりの高率で行われていることがわかった。 また，切 除後の再建方法をみると, 結腸再建が施行された症例 は14例 (77\%), 空腸再建が 4 例（23\%）であり，結腸 を再建㵴器として用いる症例が多かった。自験例も切 除可能であり，右半結腸を再建に用いた。

挙上胃管癌発生後の予後をみると, 生存期間は23日 から最長 7 年 9 か月まで平均 15.6 か月である。これを 切除, 非切除例にわけて検討した。切除例では生存期 間は23日から 7 年 9 か月で平均 18.5 か, 非切除例で は生存期間は 1 か月から 1 年で平均 5.1 只であり，切 除可能であればかなり予後は良好であると思われる。 そこで, 切除率を再建経路別に検討すると, 胸壁前 $91 \%$, 胸骨後 $50 \%$, 胸腔内 $25 \%$ で, 胸壁前再建が高い 切除率を示した。さらに, 再建経路別に予後をみると, 胸壁前 20.1 か月, 胸骨後 6.6 か月, 胸腔内 4.2 か月で胸 壁前再建が他の経路にくらべ明らかに良好な成績を示 した。な拉， 3 年以上生存した 4 症例の再建経路は全 例胸壁前であり ${ }^{10) 13) 15)}$ ，これを裏付ける成績であった。 この理由としては, 腫瘤触知などで比較的早い時期に 発見される可能性が高いこと, 他の経路より挙上胃管 の切除が容易であることが考えられよう。自験例も胸 壁前再建がなされて怙り，挙上胃管癌の切除が可能で あったが，残念ながら腎不全を併発し，5か月で他病 死という不幸な転帰となった。挙上胃管癌の予後は, 2 つの癌腫の進行程度に左右されることは無論である が, 切除さえできれば, 最長 7 年 9 か月と長期に生存 した症例も報告されており ${ }^{10)}$, ある程度予後は期待で きるように思われる。

\section{むすび}

食道癌術後 3 年 10 月年上胃管に胃癌の発生をみ た 1 例を報告, 本邦における症例を集計し検討した。 挙上胃管癌という面から食道癌手術の再建経路をみれ ば，胸壁前経路が有利と考えられる。しかし，いかな る経路で再建がなされたにせよ, 食道癌の術後は, そ の再発のチェックに加えて, 挙上胃管の定期的な検索 が必要であることを強調しておきたい。
文献

1）磯野可一，小野田昌一：食道癌治療のプロトコ一 ル。臨外 42:703-713, 1987

2）阿保七三郎, 三浦秀男, 工藤 保活か：食道癌と他 歲器重複癌。外科 Mook $24: 119-127,1982$

3）食道店患研究会編：臨床病理食道癌取扱い規約. 第 6 版. 金原出版, 東京, 1984

4）胃癌研究会編：胃癌取扱い規約. 改訂第11版. 金原 出版, 東京, 1985

5) Billroth $T$ : Die allgemeine chirurgische Pathologie und Therapie in 51 Vorlesungen. ein Handbuech fuer Stuedierende und Aertzte. 14 Aufl., S. 908, G. Reimer, Berlin, 1879

6) Warren S, Gates $O$ : Multiple primary malig. nant tumors, a survey of the literature and a statiscal study. Am J Cancer $16: 1358-1414$, 1932

7) Goodner JT: Cancer of the esophagus, Its association with other primary cancers. Cancer $9: 1248-1252,1956$

8）中山恒明, 柳沢文憲, 磯野可一活：食道胃重複癌 の 7 例について。癌の臨 $9: 248-255,1963$

9）森昌造, 渡辺登志男, 及川 佰汪加：食道胃重複 癌, 胃切除後食道癌に対与る外科的治療. 手術 $26: 687-693,1972$

10）秋山洋，山绮善弥，藤森義蔵注食道・胃重複 癌について一再建食道に生じた胃癌一。外科治療 28 : 245-249, 1973

11）飯塚紀文, 平田克治, 塩見陽面活加：食道癌根治術 後の再建胃管癌の 2 症例と重複癌に対する考察. 胃之腸 $12 ： 433-438,1977$

12）幕内博康, 中崎久雄, 三富利夫ほか：食道癌術後の 再建胃管に発生した胃癌一自験例 2 例と本邦報告 例の集計一. 日気管食道会報 $31: 238-245,1980$

13）井手博子, 遠藤光夫, 檄原 宣ほか：胸部食道癌切 除後胸壁前举上管に発生した胃癌の 4 症例. 外 科治療 $37: 220-225,1977$

14）奥島憲彦, 高田忠敬, 福島靖彦ほか：左腋窩リンパ 節転移を併なら挙上胃に発生した癌の 1 手術例。 臨外 36:1325-1331, 1981

15）佐故宏治, 松田光郎, 宇賀神若人ほか：食道癌根治 術後の移植胃管に発生した胃癌の 1 症例。埼玉県 外科医会誌 $1983 ， \mathrm{p} 916-920$

16）紙田信彦, 朝田農夫雄, 山口義友活か：食道癌手術 後 6 年後に発生した再建胃管癌の 1 例. 臨外 $39: 693-696,1984$

17）本田 拓, 青木茂弘, 伊藤 久ほか：食道癌根治術 後再建胃管に発生した胃癌の 1 手術例. 外科 $46 ： 1549-1552,1984$ 